\title{
26. Dams on the Mekong
}

\author{
Stuart Orr \\ WWF International, Switzerland
}

Recent research carried out by World Wide Fund for Nature (WWF) and The Australian National University (ANU) reveals the indirect impacts of 11 dams that are proposed to be built on the mainstream of the lower Mekong River (Orr et al. 2012). The study evaluates the volume of additional water (i.e., the water footprint) and area of land (i.e., the land footprint) that would be required for the four Lower Mekong Basin (LMB) nations to replace calorie and protein loss from changes in fish catches following dam construction.

The water footprint and agricultural land analyses presented in this study are based on the available data. While limitations on this data mean that the specific results may be contested, the research highlights the need for a more detailed understanding of the indirect consequences of the proposed dams in order to better inform decision-making.

\section{Background}

A recent strategic environmental assessment (SEA) of hydropower on the Mekong mainstream concluded that such projects would have significant negative impacts on both the fishery and agricultural sectors (International Center for Environmental Management (ICEM) 2010a, 2010b). The losses in fisheries due to the mainstream dams were estimated to be US\$476 million per year, excluding effects on the coastal and delta fisheries. In addition, the assessment found that 54 per cent of all riverbank gardens along the Mekong would be inundated, which, combined with losses in agricultural land for reservoirs and transmission lines, was estimated to cost US\$25.1 million per year.

Estimates of the freshwater fisheries catch in the LMB vary and, as such, WWF has relied on the most recent Mekong River Commission (MRC) assessments for the purposes of this research (Baran and Myschowoda 2009). On the basis of this data, the annual yield is estimated to be around 2.6 million tonnes, or two per cent of global marine and freshwater fisheries landings. The per capita freshwater fish consumption in the region is 33.7 kilograms per year, or around 80 grams per person per day for each of the 60 million people in the basin. The economic value of the LMB wild migratory fishery is US\$2.5 billion. 
Global Water: Issues and Insights

\section{Research}

The research undertaken by WWF and the ANU estimated the land and water requirements for alternative livestock protein sources, assuming that the 11 proposed mainstream dams lead to a reduction in fish production of 60-70 per cent, which is a major source of dietary protein for the people of the lower Mekong basin.

It is important to note that people might adopt any number of dietary habits to substitute the loss of calories and protein from fish. The dynamics of consumer behaviour are complex and this study was limited to the most plausible scenario: that the share of meat proteins consumed in the LMB nations would increase in response to a fall in fish production. While vegetable protein intake could also increase and would come with its own costs, such scenarios have not been considered in this research and should be explored in further research.

By assuming an increase in the demand for meat protein to replace lost fish catches, our calculations suggest that water consumption for livestock protein production - the water footprint - will increase from six per cent to 17 per cent and will be considerably higher in Cambodia and Laos. Southeast Asia as a whole is not water scarce; however, such a major increase in consumption is likely to have significant opportunity costs. Substantial volumes of water in the natural environment are needed to sustain important ecosystem services in the basin, such as capture fisheries, low-input flood recession agriculture and maintenance of the delta. The proposed hydropower reservoirs would have a land footprint of at least 14,865 square kilometres $\left(\mathrm{km}^{2}\right)$-including $1350 \mathrm{~km}^{2}$ of land proposed to be inundated for the dams - and this area of land includes some of the most productive riverside farmland in the LMB.

In addition, the area of pasture land required to replace fish protein with domestic livestock was estimated to range from 7080 to $24,188 \mathrm{~km}^{2}$ (13 per cent to 63 per cent). This will not be easy given that high quality agricultural land in the region is already occupied and agricultural rates of conversion are stagnant.

Consequently, the change in protein away from local river fisheries will have substantial social, economic and environmental implications, including greater water consumption, land use conversion and greater reliance on imports. Increased food prices associated with higher costs of livestock production could impact the poor and exacerbate poverty.

The supporting institutional and investment infrastructure required to accommodate these changes is substantial, yet the issues of ensuring that dam construction does 
not impact the food sources of vulnerable populations have been overlooked. All stakeholders should be entitled to know what alternatives and strategies are in place for any situation where basic food supplies are at such a high risk of disruption.

\section{Conclusion}

Hydropower development is often justified by the projections of social and economic advantages, using assessment processes that are narrowly focused on the environmental and social impacts of the areas directly impacted by dam construction and inundation (World Commission on Dams (WCD) 2000). Indeed, the current assessment processes underway for the proposed dams on the main stem of the LMB appear to mirror this approach.

The data used in our assessment is the best available and these findings are first approximations of land and water requirements resulting from the proposed dams. The methods adopted here to estimate the impact on protein supplies due to dam construction are conservative in the use of SEA assessments of the loss in fish production and scaling up supply of other proteins in proportion to their existing consumption.

Further, the data used here does not yet account for future population increases and resulting demand for protein. Similarly, other possible protein scenarios could be modelled and would add considerably to a wider understanding of the impacts and options available. Comprehensive estimations are required to establish detailed accounting of food costs, land and water use and access, livelihoods, equity and poverty. Studies for individual nations would determine a wider range of impacts and should be used to explore the institutional challenges that lay ahead. In this manner, the benefits of dams can be better compared to the negative trade-offs involved.

Regulatory authorities for these dam projects have an obligation to draw on the best available data to ensure their decisions optimise the benefits for their citizens and the environment.

Stuart Orr has been with WWF since 2006 and works with the private sector on a range of water-related issues. Orr has published mainly on water risk and water stewardship and has recently co-drafted guidelines for the United Nations compact on corporate engagement in water policy. He has an academic and research background in agricultural systems and water resource management and has worked for many years in the private sector in Asia and the United States. 
Global Water: Issues and Insights

\section{References}

Baran, E. and Myschowoda, C., 2009. 'Dams and fisheries in the Mekong Basin', Aquatic Ecosystem Health and Management, 12:227-34.

International Center for Environmental Management (ICEM), 2010a. MRC Strategic Environmental Assessment (SEA) for Hydropower on the Mekong Mainstream: Fisheries baseline assessment working paper, Hanoi.

2010b. MRC Strategic Environmental Assessment (SEA) of Hydropower on the Mekong Mainstream: Final report, Hanoi.

Orr, S., Pittock, J., Chapagain, A. and Dumaresq, D., 2012. 'Dams on the Mekong River: lost fish protein and the implications for land and water resources', Global Environmental Change 22(4):925-32.

World Commission on Dams (WCD), 2000. Final report. Available at http://wwf. panda.org/what_we_do/footprint/water/dams_initiative/dams/wcd/. 
This text taken from Global Water: Issues and Insights by R. Quentin Grafton, Paul Wyrwoll, Chris White and David Allendes, published May 2014 by ANU Press, The Australian National University, Canberra, Australia. 